\title{
Medical journals and the mass media: moving from love and hate to love
}

\author{
Richard Smith
}

J R Soc Med 2006;99:347-352

Richard Smith was editor of the BMJ and chief executive of the BMJ Publishing Group for 13 years. In his last year at the journal he retreated to a 15th century palazzo in Venice to write a book. This is a much shortened version of a chapter from his book, The Trouble With Medical Journals that the RSM Press will publish later in the year [http://www.rsmpress.co.uk]. This is the 5th in a series of extracts that will be published in the JRSM.

Medical journals are the main conduit by which medical research reaches the public; and the public seem to be ever more interested in medical stories. Consequently, the mass media pay ever more attention to medical journals. In Britain Friday morning is 'Lancet and BMJ' morning. Virtually every week the morning's media will include stories from one or the other, and often both; although editors may sometimes be critical of the media, they love the attention. But is this passion for publicity corrupting the journals? Should the journals, far from courting the mass media, be keeping them at a distance?

\section{LESSONS LEARNT FROM MY EXPERIENCES IN THE MASS MEDIA}

I have experienced the vicissitudes and power of the mass media at first hand. For 6 years I was a 'television doctor' for 4 years on BBC Breakfast Time and 2 years on TV-AM. I have also made a few television programmes. These experiences taught me some things about the media that it may be useful briefly to share.

Very scared, I appeared first on a live programme broadcast late at night in Newcastle - 'a programme made by drunks for drunks'. As I came off the set, the producer said to me: 'You were wonderful, a natural television personality'. Three hours and a few drinks later she said: 'You were awful. I couldn't understand a word you said'.

\section{Lesson 1: beware the flattery of the media.}

When it came to the first programme on BBC Breakfast Time, the producer asked me what we might discuss.

Chief Executive, UnitedHealth Europe

E-mail: richardswsmith@yahoo.co.uk
'What about heart disease?' I suggested. 'It kills half the population.' 'But is there enough to talk about for three minutes?' the producer asked.

Lesson 2: time is very short on television and becoming shorter, but 15 seconds talking to 10 million people is the same amount of time as 10000 people spending 4 hours reading the book of which this article will form a part-which is unlikely to happen.

One week in the early 1980 s the Lancet published a complex study that suggested that certain sorts of contraceptive pill were associated with breast cancer. This was the first time that most people, including me, had heard of the link. It was hard to make sense of the study, and the Lancetunfriendly in those days to the media (and perhaps readers) - had no press release and no editorial discussing the possible importance of the findings. I had to explain the findings at the peak spot on the programme with Dame Edna Everidge, a famous female impersonator, in bed beside me. When asked about the safety of the pill, she said: 'As long as I keep the pill between my knees it's safe and it works'.

Lesson 3: those of us who work in calmer circumstances should recognize the difficulties faced by those working in the mass media.

On Thursday afternoons I would tell the producers about stories emerging from that week's Lancet and BMJ. 'Too boring,' they would often say. But then they would ring me at 4 am about a 'fantastic story' that they'd read in the morning's papers. It was often the story they had pronounced too boring.

Lesson 4: the media are like lemmings. They want to break stories but they are confident that a story is a true news story only when they see it somewhere else.

I was keen to discuss both AIDS (then a new disease) and testicular cancer on the programme. The producers were unwilling to discuss either-because AIDS was a disgusting disease and the British could not tolerate talk of testicles over breakfast. A friend working at the time on the 
Guardian, Britain's most liberal national newspaper, was told he could not use the phrase 'anal intercourse'.

Lesson 5: the mass media can be very prudish.

One morning, prompted by a strange episode, I told the presenter that you had to be ready for anything in medicine. 'What strange things have you seen recently?' he asked.

I did not see patients, and the only thought that came into my mind was that I had had two letters from women who were worried that they might be pregnant by dogs (probably, in retrospect, spoofs). I wondered whether to mention this but then did. Feeling obliged to answer the question, I said: 'Of course, you can't be, although' I added, trying to be interesting, 'you could perhaps be pregnant by a gorilla'. Afterwards the producer asked me if I was aware that this was live television.

Lesson 6: live media can lead you to some very strange places.

Finally, I remember the day when a woman rang me from Leeds Station to say that she was about to get on a train to bring her blind daughter to see me. 'I'm sure, doctor, that you can cure her. I've seen you on the television.' With difficulty, I dissuaded her.

Lesson 7: the media can have remarkable power.

\section{JOURNALS COURTING THE MEDIA THROUGH PRESS RELEASES}

The world of live, mass market television is very different from the world of medical journals; but some medical journals are getting close to the mass media. Most major journals employ at least one press officer and put out a press release with each issue. The $B M J$, for example, puts out a press release each week that usually describes four or five 'stories' from the BMJ. The press release is faxed or emailed to hundreds of journalists around the world, and is placed on websites accessible only to journalists.

What should be included in a press release? It is tempting to include studies that are 'important' in that they describe new evidence on common and important diseases. These are the things in which the media ought to be interested - and sometimes they are. But often they are not. 'Worthy but dull' is the withering judgement from newspaper editors. The media are interested in things that are new, exciting, amusing, and likely to appeal to the public's interest (quite a different thing from the public interest). They are particularly interested in 'counterintuitive stories' - 'man bites dog' rather than 'dog bites man'. Sex, alcohol, food (especially for some odd reason alternative therapies are perennial favourites. The media are increasingly a branch of the entertainment industry, competing desparately with a thousand other interests for people's attention. (This is true as well of journals.)

What should be the style of a press release? One option is to write a complete story that could be placed straight onto the page by penurious publications, of which there are many. This is what some journals do, but the $B M J$ chose not to. We saw the press release as a taster. We wanted the journalists to read the paper and speak to the authors and perhaps others. In other words, the journalists would 'add value', enrich the story, and move it on. Another view is that journals should energetically try to help journalists make sense of the story in order to avoid 'scares'. So journals might, for example, give various ways of presenting risk. They might explain not only that a pill causes a 50\% increase in risk, but also that the risk goes up from two in a thousand per year to three in a thousand per year.

\section{SHOULD JOURNALISTS, DOCTORS, AND PATIENTS ALL HAVE ACCESS TO NEW RESEARCH AT THE SAME TIME?}

Journalists can get electronic access to the studies under embargo before they are released to the rest of the world. One argument for an embargo is that it gives journalists time to interview people and prepare a clear and accurate story. Another argument is that the embargo prevents an unseemly scramble, with journalists trying to outdo each other. The embargo also means that doctors will be getting their paper copies of the journal at the same time that stories are appearing in the media. If a study evokes a 'scare' — as the Lancet pill study did, with tens of thousands of women stopping the pill-then doctors have full information for advising patients.

Many doctors would prefer to have the full information before a media blitz occurs. They would then be prepared. Unfortunately, this is unachievable in a world of instant electronic communication. The moment a publication is publicly available it circles the world. The embargo is a compromise, which journalists accept because it makes their lives easier — but it would be impossible to enforce an embargo that was even hours after doctors got their copies.

Some journalists also object to embargoes, on the grounds that journalists are being manipulated and that journalistic values are being undermined. Important stories should not 'in the public interest' be held back for even a few moments, let alone 2 or 3 days. Independent Television News took this line with the $B M J$ a few years ago, and we threatened not to provide them with a press release. They pointed out that this was an empty threat because they had links with dozens of news organizations around the world and would have no difficulty getting our press release. We 
argued that the embargo worked in everybody's best interest and that they would drive us back to a world of the mad, midnight scramble. I am not sure if they agreed, but something stopped them breaking our embargo.

In a global world of 24-hour media, the time of the embargo works well for some people and badly for others. For years both the BMJ and the Lancet had the same embargo of $00.01 \mathrm{am}$ on Friday morning - ideal for a gentlemanly world where journals had limited coverage in the Times, the Guardian, and other 'quality dailies'. But there are now tens of thousands of media outlets, and most are electronic - not only radio and television but also web based. ITN argued to the BMJ that Britain had now followed the USA in television being everything. The newspapers, they told us, are giving yesterday's news. They would like an embargo that was $6 \mathrm{pm}$ Thursday evening - then they could break the stories first. But that would upset the doctors: patients would be getting information 12 hours before they did. It is a world of uneasy compromises, but the BMJ moved embargo back to $11 \mathrm{pm}$ on Thursday to catch the evening broadcasts in the USA, the world's only superpower as readers will hardly need reminding.

\section{DEATH OF THE 'THE INGELFINGER-RELMAN RULE'}

Journals used to be very proprietorial over their studies. The New England Journal of Medicine had something called 'the Ingelfinger-Relman rule', named after two of its editors. ${ }^{1}$ The rule said that if the journal saw even a whisper of one of their studies in mass media then they would decline to publish the study. This was very threatening to authors-because getting published in the New England Journal of Medicine was supremely important. The journal's argument was that material should not be released until properly peer reviewed. Another argument, a much better one to my mind, was that the world needed access to the full study in order to be able to decide whether to believe the results. Simply presenting the conclusion of a study could be very misleading. The journal also wanted a reward for investing so much time and energy in a study. It did not want its thunder stolen.

Many journalists objected strongly to the rule, arguing that journals were holding back information, much of it funded with public money, that was important for public health and interfering with the free flow of information. Surely journals should be promoting the dissemination of information, not impeding it. There was also a problem in that the rule stopped scientific discourse. The rule might have worked acceptably in the days when scientists met in closed meetings, but increasingly journalists attend scientific meetings. Indeed, the major societies that hold the meetings increasingly employ public relations companies to publicize
Table 1 Google searches, 2003 and 2006, for quotations in 4500 internet-based news outlets

\begin{tabular}{|c|c|c|c|}
\hline \multirow[b]{2}{*}{ Journal } & \multicolumn{2}{|c|}{$\begin{array}{l}\text { Google news } \\
\text { hits }\end{array}$} & \multirow[b]{2}{*}{$\%$ change } \\
\hline & 2003 & 2006 & \\
\hline JAMA & 1620 & 3070 & 87 \\
\hline New England Journal of Medicine & 1550 & 3060 & 97 \\
\hline Lancet & 580 & 2100 & 262 \\
\hline BMJ & 412 & 1240 & 200 \\
\hline Annals of Internal Medicine & 179 & 190 & 6 \\
\hline $\begin{array}{l}\text { Journal of the American College of } \\
\text { Cardiology }\end{array}$ & 165 & 28 & 489 \\
\hline British Journal of Psychiatry & 18 & 38 & 111 \\
\hline Canadian Medical Association Journal & 17 & 139 & 718 \\
\hline Public Library of Science Medicine & $\mathrm{n} / \mathrm{a}$ & 115 & $\mathrm{n} / \mathrm{a}$ \\
\hline Medical Journal of Australia & 22 & 71 & 223 \\
\hline Archives of Disease in Childhood & 0 & 3 & Infinity \\
\hline Annals of Rheumatic Diseases & 0 & 0 & 0 \\
\hline
\end{tabular}

the meeting and the studies being presented. Authors became very confused. Could they not present their studies at meetings? If not, surely that meant that journals were standing in the way of scientific debate, something essential to the scientific process?

The BMJ operated a dilute version of the IngelfingerRelman rule and would explain to authors that we did not mind them presenting at meetings but that they should not give any data to journalists or talk to them. But this seemed to be a formula for encouraging stories that are misleading. Slowly, but surely, the rule collapsed, and the $B M J$ gave up worrying about where material appeared before it was in the BMJ. Everybody tends to agree, however, that it is best if media stories and full scientific reports can appear simultaneously - otherwise, the world may be left wondering whether it is true that 'porridge cures (or causes) cancer'.

\section{INCREASING MASS MEDIA COVERAGE}

Producing press releases may create various problems, but they seem to be effective in producing coverage of studies from journals in the mass media. Table 1 shows the results of a search that I did on Google in July 2003 and again in April 2006 to see how much various journals had been quoted in some 4500 internet-based news outlets from around the world in a 4-week period.

As with all data it is fascinating to try and draw meaning from them. These are the messages I draw. 
- there is considerable coverage in the mass media of material from medical journals

- the vast majority of the coverage comes from the major general medical journals

- the American weekly medical journals dominate

- the coverage received by the journals seems to correlate with their prestige and their impact factor

- the non-American general journals have seen the biggest percentage increase in coverage. This is probably the result of the internet making the nonAmerican journals much more available to the American media, which tend to dominate. The huge percentage increase in coverage of the Canadian Medical Association is largely caused by the controversy surrounding the recent sacking of the editors.

\section{WHY DO JOURNALS WANT COVERAGE IN THE MASS MEDIA?}

Why do journals want this coverage? The editors of the New England Journal of Medicine used to give the impression that they saw coverage in the mass media as a necessary evil. This was ironic in that the journal's pre-eminent position was closely linked with its extensive coverage in the mass media.

Indeed, the journal published a clever opportunistic study in 1991 that looked at how coverage of studies in the New York Times affected citation in scientific journals. ${ }^{2}$ Those studies from the New England Journal of Medicine that were reported in the New York Times received more citations for every year of the next 10 years than those not reported. In the first year after publication they received roughly $80 \%$ more citations. Thoughtful readers might think that this is simply because the New York Times reported the most important studies. But during the study it went on strike for 3 months. The journalists continued to produce a newspaper of record, but it was not distributed. Those articles that were selected from the New England Journal of Medicine during the strike did not receive more citations. So it seemed to be the coverage itself that increased citations.

The result is probably not surprising. Scientists pay attention to the mass media, just like everybody else. The studies selected will thus be brought to their attention; and almost certainly being reported in the New York Times would be closely related to being reported in other media, including international media. Several studies have also shown that doctors get much of their new medical information from the mass media. They are overwhelmed with information. It is very convenient to have studies selected and professionally presented by the mass media, particularly television. Instead of tired doctors having to struggle through the complexities of a scientific study, they can slump in front of the television and have the story told to them attractively - and often by the authors - in 2 minutes.

So one reason to seek media coverage is to increase citations to your journal-something that obsesses many editors in this age of academic accountability based on the impact factors of journals. Next, ironically, you may reach your own readers more effectively through the mass media than through your own publication. Certainly you will reach a huge audience of researchers and doctors who you will not reach directly through your journal.

Then for many journals - and certainly the BMJ - it is a desirable end in itself to reach the public. Much of the research journals publish is funded with public money and all of it is intended to improve the health of individual patients or the public. The logic of the age of patient partnership is that patients and the public should have access to research.

Dissemination of journal material through the mass media is also part of the political process. Improving health is in many ways a political activity, and journals are much more likely to have a political impact if their contents - and not just research but also editorials - are covered in the mass media. Politicians pay much more attention to the mass media than they do to medical journals.

Coverage in the mass media is also very gratifying for all those involved in journals. Some may pretend to be too high minded to care, but almost everybody loves the coverage. These days authors may find themselves doing 50 interviews in a day. They rub shoulders with celebrities that they otherwise only see in Hallo magazine, and their words, wise or otherwise, may be broadcast across all six continents. Their research reaches not just a few buddies but millions. Their mothers are excited. Old friends from Australia that they have not heard from for years e-mail them. And their universities and funders - hungry for prestige and cashlove it. This is why they employ public relations companies to get authors into as many media as possible. Many authors find a day or two being feted by the media very exciting after years of careful and unglamorous analysis of data. Because authors and their institutions like media coverage they are more likely to submit their studies to journals that receive much coverage, providing another reason for journals to pursue the mass media.

Editors and the staff who work on journals also like media coverage. It feels like a public affirmation of their work. Then the business and marketing people like it too. Coverage in the mass media is a highly cost effective way to get your journal known, and some journals have broken into new geographical markets by targeting the media. So there is probably a long term financial return for coverage, but these days there is also a short term return. Many journals have a 'pay per view' facility on their websites. People can pay about US\$10 with their credit card to get 
instant access to an article. Unsurprisingly, studies covered in the mass media are the ones that attract most of this income.

\section{PLAYING WITH THE MEDIA IS PLAYING WITH FIRE}

Playing with the media-particularly the more downmarket media - is, however, playing with fire, and it can get very rough. Jim Drife, a professor of obstetrics and gynaecology and one of the BMJ's columnists, discussed the case for women at high risk of breast cancer having bilateral mastectomies as a preventive measure. He was then depicted as a monster in the media. Various doctors in prominent positions played down the idea that bovine spongiform encephalopathy could cross from cows to man and then were ridiculed when it did. But mostly authors presenting research in the mass media are given an easy ride. The presenters and journalists simply want to tell the story as clearly as possible. They rarely challenge it.

\section{DO EDITORS FAVOUR ARTICLES THAT WILL GAIN MEDIA COVERAGE?}

So if editors are so attracted to media coverage are they more likely to accept studies that will attract such coverage? Did the Lancet accept the infamous study that linked the measles mumps rubella (MMR) vaccine with autism because of its taste for publicity?

If medically and scientifically important studies were also the studies most likely to get media coverage, then there would be no problem. But they are not quite the same thing. 'Skateboarding duck stories', as we called them at the $B M J$, will get coverage, but are not medically and scientifically important. But then again, the media select such stories because they think their readers will like them, and the readers of the $B M J$ are not so completely different from the rest of the population: they will probably enjoy them too. Medical journals like the BMJ are poised somewhere between academia and journalism and have some journalistic values. The $B M J$ would not, I like to think, take a piece of research that was scientifically ridiculous but journalistically exciting, but journalistic value is a factor it considers.

I remember a debate over a paper we published in our Christmas issue, an issue traditionally devoted to slightly strange, wacky, and amusing material. A long-term follow up of a population in Wales showed that men aged 40 who had 50 orgasms a year lived longer than those who had fewer. ${ }^{3}$ There would inevitably be doubts over the data. How honest are people about their sex lives? Perhaps the fact that the men had more orgasms was simply a marker of other characteristics that made them likely to live longer. Or maybe healthier men were capable of more orgasms.
This study was neither medically nor scientifically important, but it would interest our readers and get lots of media coverage. I decided that we would publish the study_ — and it did get lots of coverage.

\section{WHAT IS THE QUALITY OF COVERAGE?}

I see it as largely beyond the scope of this article to discuss how the mass media cover medical stories, some of which come from medical journals, but I want to make a few comments. There is no doubt that coverage of health issues in the mass media is increasing, and it may be that the increased coverage is contributing to patients becoming as smart as their doctors, changing forever the relationship doctors and patients. Knowledge is power, and increased knowledge must be a good thing.

Increased information does not, however, equal increased knowledge. Ann Karpf, a journalist and sociologist, has argued that the increased coverage is leading to more confusion. ${ }^{4}$ People are often misinformed. The mass media do a mostly competent job of reporting on new studies, although the complexities, the 'ifs and buts', are inevitably left out. Feature articles on health are, however, less good. Certainly in the British media, health is mixed together with beauty and fitness, and there is a great enthusiasm for alternative treatments. The Observer, one of Britain's oldest newspapers, for years ran a column by 'the barefoot doctor'. He published amiable, and perhaps helpful, tosh. Probably people, including my wife, who read his columns, understood the nature of what they were reading, but I find it hard to believe that the postmodern mishmash served up by the media is helpful.

Then there are the recurrent 'scares', many of them it has to be said started by medical journals. The scare over the measles mumps rubella is familiar to everybody, but we have had scares over whooping cough vaccine, brain death, the contraceptive pill, toxic shock syndrome, 'mad cow disease', total allergy syndrome, the 'flesh eating bug', and many other issues. Mostly these scares contain some genuine cause for worry, but the 'flesh eating bug' scare was a classic scare story. A journalist somewhere discovered a case of necrotizing fasciitis, a rare but well recognized condition caused by a bacteria. A subeditor added the sobriquet of the 'flesh eating bug', and editors around the country began a search for cases. Even with a rare disease you will find cases if you do not restrict yourself in time and space. Suddenly, the media were full of accounts of cases of a dreadful disease that nobody had heard of before. It seemed as if a new disease was rampant. Knowledgeable health reporters tried to explain to editors that there was nothing new, but they were swept aside. Eventually the story fizzled out, but many people must have lain awake at night worrying that the disease would soon strike them. 
Stories in the media can always get out of control, and the mass media are probably even more prone than medical journals to manipulation by those with vested interests. The San Francisco Chronicle, for example, carried a piece extolling the virtues of prostate specific antigen (PSA). The article suggested that every man who was middle aged or older should know his PSA. The editors of the Western Journal of Medicine - friends of mine - wrote a letter to the newspaper saying that its piece had overstated the case for testing men. Screening all men for prostate cancer is not recommended by public health authorities, and mass testing might well create more problems than it solves - partly because many men will be made unnecessarily anxious and partly because many older men have prostate cancer and yet will not be troubled by it. The Chronicle, to its credit, liked their letter and asked them to write a full article. They did, and within moments of publication they were subjected to a firestorm of abuse. They were accused of 'geriatricide', and several people wrote to their employers - in one case, the University of California-demanding they be sacked. Urologists, many of whom stand to benefit financially from increased PSA testing, led the charge.

\section{CONCLUSION}

I am an unapologetic populist, and I believe that medical and health issues should be debated in the mass media, but we would probably all benefit from there being more places where there could be a higher level of debate. Perhaps medical journals have a role here and perhaps they should consciously try to appeal more to non-doctors.

Medical journals are moving, I believe, from being rather offhand about - or even sometimes hostile tomedia coverage to liking it. Doctors and academic institutions are moving in the same direction. My hope, however, is that journals' engagement with the mass media will enhance not debase the value of what they publish. I have to say that I am much less worried about journals' involvement with the mass media than I am with their involvement with the pharmaceutical industry.

\section{REFERENCES}

1 Relman AS. The Ingelfinger rule. N Engl J Med 1981;305:824-6

2 Phillips DP, Kanter EJ, Bednarczyk B, Tastad PL. Importance of the lay press in the transmission of medical knowledge to the scientific community. N Engl J Med 1991;325:1180-3

3 Davey Smith G, Frankel S, Yarnell J. Sex and death: are they related? Findings from the Caerphilly cohort study. BMJ 1997;315:1641-4

4 Karpf A. Doctoring The Media: The Reporting of Health And Medicine. London: Routledge, 1988 